\title{
The Issue of Copyright Infringement in 4.0 Industrial Revolution: Indonesian Case
}

\author{
Yati Nurhayati, Ifrani, Abdul Halim Barkatullah, M. Yasir Said \\ Faculty of Law, Universitas Islam Kalimantan MAB, Indonesia, E-mail: yatinurhayati1904@yahoo.com \\ Faculty of Law, Universitas Lambung Mangkurat, Indonesia, E-mail: ifrani@ulm.ac.id \\ Faculty of Law, Universitas Lambung Mangkurat, Indonesia, E-mail: ahbarkatullah@ulm.ac.id \\ Postgraduate School of Law, Universitas Lambung Mangkurat, Indonesia, E-mail: \\ yasirsaid93@gmail.com
}

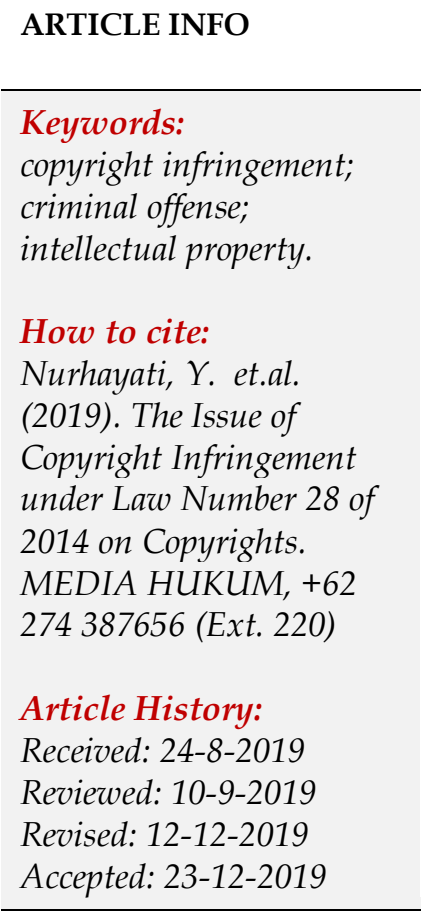

\begin{abstract}
Industrial revolution has substantially changed the economy and society. The fusion of technologies and information marked the fourth industrial revolution which brings about new challenges relating to protection of intellectual property, including copyrights. With regard to this, there has been several changes in the law relating to copyrights in Indonesia. The nature of copyright infringement has been changed from ordinary offense to complaint-based offense. This fundamental change undoubtedly affects the enforcement of the copyright law in Indonesia. Thus this paper aims to answer and review the legal reasoning behind the shift in offense in Copyright Law in Indonesia. This normative legal research employed a descriptive-analytic method. The result shows that the complaint-based offense is suitable in copyright protection considering that only the copyright owner knows the details of the object of the creation.
\end{abstract}

DOI: 10.18196/jmh.20190128

Copyright (C) 2019 MEDIA HUKUM. All rights reserved.

\section{Introduction}

The development of the Industrial Revolution has substantially changed the economy and society. The word "development" seems to indicate detention in the context of "revolution," which shows rapid changes; however, there is no doubt that significant alterations occurred in a short time. ${ }^{1}$ The First Industrial Revolution was indicated by the used of water power and steam for mechanical production. While the Second Industrial Revolution (2.0) developed the used of electricity to create massive production. The Third Industrial Revolution showed a combination of electronics and

1 Bloem, J. et. al. (2014). "The Fourth Industrial Revolution, Things to Tighten the Link between IT and OT." VINT Research Report 3: 11. 
information technology to automatically produced goods. ${ }^{2}$ While today, the Fourth Industrial Revolution (4.0) is developing the foundation of the Third Industrial Revolution (3.0). The Digitalization of Industrial Revolution (Digital Revolution) has been occurring since the last century. The 4.0 industrial revolution shall combine the most sophisticated technologies and techniques that will undoubtedly change the production. The fusion of technologies and information marked the fourth industrial revolution that reduced the lines between the physical, digital, and biological spheres. ${ }^{3}$

The universal challenges of the industrial revolution era are in designing the policies and laws to be implemented in the latest development. Intellectual Property (IP) plays an essential role in industrial legal protection. In the penal aspect of IP protection in Indonesia, there are two types of offense, ordinary offenses and complaint-based offense. The criminal offense is one of the essential things that underlie the amendment to Copyright Law Number 28 of 2014. In the 2002 Copyright Law, Article 72 (1) categorizes violations of rights as a normal crime. The normal crime follows the primary nature of criminal law, in which it is independent of the agreement or complaint from the aggrieved party. Whereas it is known in general, that most of the practices of the state regulate the threat of criminal penalties against violations of IP is a complaint offense.

Furthermore, looking back in Indonesian legal development on Copyright protection, there have been several changes in regulations. One noticeable difference is the use of penal sanction through penal offense, which keeps changing between normal and complaint offense. This fundamental change is undoubtedly affecting the enforcement of copyright law in Indonesia. Therefore, it is interesting to study the extent of legal protection from a penal perspective. Thus the paper aims to find the legal reasoning behind the change of penal offense in Copyright Law in Indonesia while also provide an understanding of the penal politics in copyrights protection in Indonesia.

\section{Method}

The research method has a vital role in the research and development of knowledge because it has several functions. Among others, is to increase the ability of scientists to conduct or carry out research better, or more fully and provide greater possibilities to examine the unknown, especially in legal research ${ }^{4}$ It is vital to measure the meaning and validity of law to be used for legal reasoning to prescribe and guide the future of judicial decision-making. ${ }^{5}$

Therefore, the study uses normative legal research. The type of research will refer to the legal norms contained in legislation, court decisions, and common habits. ${ }^{6}$ Data analysis of normative legal research is carried out in a qualitative descriptive manner. The legal material is then collected, sorted, and subsequently studied and analyzed for

\footnotetext{
2 Presecaru, P. (2016). "Challenges of the Fourth Industrial Revolution." Journal of Knowledge HorizonsEconomics, 8(1): 57.

3 Scwhab, K. (2016). "The Fourth Industrial Revolution: what it means, how to respond," 14 January 2016,

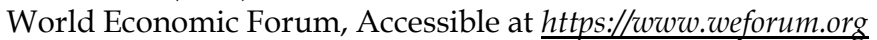

4 See Barkan, S.M. (1982), “On Describing Legal Research." Michigan Law Review, 80(4): 925.

5 McCrudden, C. Legal Research and Social Sciences. in Mar, M.D \& Giudice, M (ed). (2017). Legal Theory and the Social Sciences. New York : Routledge, p. 19.

6 Fetterman, D.M. (1998). Ethnography Step by Step. London: Sage Publishing, p. 175.
} 
content, so that the level of synchronization, the feasibility of norms, and the submission of new normative ideas can improve.

\section{Analysis and Results}

\subsection{General Review on IP Protection}

Intellectual Property (IP) ${ }^{7}$ First appeared in Venice (Italy) in 1470 and only related to patents then adopted by the British Empire in the 1500s and began to be taken by many countries in the world and harmonized in 1883 with the approval of the Paris Convention for the patent, trademarks, and designs. ${ }^{8}$ Substantially, the definition of IP can be described as a property rights that rosed due to human intellectual abilities. ${ }^{9}$ The object protected by law is the idea, not the material form of IP incarnation. The reason is that IP is an exclusive right that only exists and is attached to the owner or right holder. ${ }^{10}$

IP is intellectual property protected by law. Legal protection of IP is upon two reasons: First, because there is a moral right reflecting the personality of the creator in IP. Secondly, because of economic factors or commercial rights contained by intellectual work. The last factor drives countries in the world to provide full and firm legal protection toward intellectual work. ${ }^{11}$

The Copyright Law is a concept adopted from the protection of international IP. The copyright gives the creator a right to control and use his creation, which, in essence, serves to prevent other parties from copying their work without permission. ${ }^{12}$ Internationally there are many definitions or terminology relating to Copyright, although each country member of the WIPO Copyright Treaty provides different meanings, but virtually the same understanding, which is exclusive rights for the creator and its recipient to literature and artworks. ${ }^{13}$ In Indonesia, Article 1 Paragraph (1) of Law Number 28 of 2014 on Copyright, defines the meaning of copyright as an exclusive right of the creator that inherent based on the declarative principle after the manifested of work in a tangible form without reducing restrictions by legislation. ${ }^{14}$ This definition provides clarity that the recognition system of copyright in Indonesia is carried out with the declarative principle (first to use or first to publish).

That creation is protected after the work has been created, recognized, heard, and published, which means that copyright in this doctrine is further than ideas. It has to be an actual manifestation of the ideas (protected expression of ideas). Whereas in Indonesia, creation is determined by publication instead of registration to obtained legal protection.

\footnotetext{
Here and after will refer to as IP.

Nurrachmad, M. (2012). Segala Tentang HAKI Indonesia. Yogyakarta: Buku Biru, p. 18.

Riswandi, B.A. \& Syamsudin, M. (2004). Hak Kekayaan Intelektual dan Budaya Hukum. Jakarta: Raja Grafindo Persada, p. 31.

10 Muhammad, A.K. (2001). Kajian Hukum Ekonomi Hak Kekayaan Intelektual. Bandung: Citra Aditya, p. 1.

11 Saidin, O. (2010). Aspek Hukum Hak Atas Kekayaan Intelektual. Jakarta: Raja Grafindo Persada, p. 111.

12 Tim Lindsey dkk. (ed). (2002). Hak Kekayaan Intelektual, Suatu Pengantar. Bandung: Alumni, p. 6.

13 Margono, S. (2003). Hukum dan Perlindungan Hak Cipta. Jakarta: Novindo Pustaka Mandiri, p. 27.

14 Suwarni, W. (2019). “Obstacles to Enforcement of Book Copyright Law in Indonesia Based on the Legal Structure, Legal Substance, and Legal Culture." International Journal of Advanced Research and Publications, 3(3): 154-155.
} 


\subsection{The Challenges of Culture and Traditional Paradigm Faced by IP}

Creativity and innovative thinking are vital in Intellectual Property. More scholars are accepting the utilitarian view on the assumptions to generate the desired-moral claims as a key to promote social utility by giving incentives for the creator's innovation in exchange for limited rights. ${ }^{15}$ However, utilitarianism as an ethical and moral theory, was attacked for failing to consider for special obligations and undermining individual integrity or even a life-long project pursuit. ${ }^{16}$ Also, even though if assuming that utilitarianism is the best theory for IP, it is still not clear if the personal ownership of IP works can be justified. ${ }^{17}$ More specifically, it would be challenging to explain lifetime plus copyrights on pragmatic grounds.

The main problem concerning the enforcement of copyright law is the issue of culture and the traditional paradigm. In the conventional view, creation is considered as shared property, and even if there is an acknowledgment of individual rights to the invention, the form emphasizes the moral aspect of copyright rather than its economic value. ${ }^{18}$ While it can argues that legal protection provides aegis. ${ }^{19}$ The theory of legal protection is a function to examines and analyzes the purpose of the protection by the law to a subject. ${ }^{20}$ The elements listed in the philosophy of legal protection include ${ }^{21}$ :

a. The form and the purpose of protection;

b. Legal subject;

c. The object of legal protection.

According to the Legal Guardian Theory by John Salmond quoted in Fitzgerald's studies, the theory of legal protection views of law aims to integrate and coordinate various interests in society because first of all, in the traffic of interest, the protection of affairs can only applicable by limiting interests of others. ${ }^{22}$ Furthermore, Djumhana describes the doctrines that developed Copyright protection as follows ${ }^{23}$ :

a. Right of Publicity;

b. Making an available right and merchandising right;

c. Fair use/ fair dealing;

d. The work made for hire doctrine;

15 Moore, A.D. (2018). "Intellectual Property and the Prisoner's Dilemma: A Game Theory Justification of Copyrights, Patents, and Trade Secrets." Fordham Intellectual Property, Media, \& Entertainment Law Journal, 28(4), p. 833. Available online at https://ir.lawnet.fordham.edu/iplj/vol28/iss4/3 .

16 Williams, B \& Smart, J.J.C. (1973). Utilitarianism: For and Against. Cambridge: Cambrige University Press, p. 5.

17 Moore, A.D. (2003). "Intellectual Property, Innovation, and Social Progress: The Case against Incentive based Arguments." Hamlin Law Review. 26(3), 602; Breakey, H. (2012). Intellectual Liberty: Natural Rights and Intellectual Property. New York: Routledge, p. 38-58.

18 Priyatna, A. (2016). "Penegakan Hukum Terhadap Pelanggaran Hak Cipta dalam Pembuatan E-Book". (Tesis). Magister Kenotariatan, Fakultas Hukum, Universitas Diponegoro. Semarang. p. 23.

19 Rahardjo, S. (2000). Ilmu Hukum. Bandung: Citra Aditya Bakti, p. 263.

20 Salim \& Nurbani, S.E. (2013). Penerapan Teori Hukum Pada Penelitian Tesis dan Disertasi. Jakarta: Raja Grafindo Persada, p. 263.

21 Rahardjo,S... Loc.Cit.

22 Teresia, R. (2015). "Perlindungan Hukum Hak Cipta terhadap Pemilik Lagu atas Perbuatan Pengunduhan Lagu Melalui Situs Tanpa Bayar di Internet." JOM Fakultas Hukum, 2(2): 5.

23 Paserangi, H. (2011). "Perlindungan Hukum Hak Cipta Software Program Komputer di Indonesia." Ius Quia Iustum, 18 (Edisi Khusus): 24. 
e. Legal protection of character right;

f. Traditional knowledge in copyrights

g. The latest development in copyright: software, free, copyleft, open-source.

\subsection{The Rules of Criminal Offense in IP Protection}

Criminal actions are prohibited by a legal rule which accompanied by the penalty through individual punishment for violating the prohibition. ${ }^{24}$ In the Dutch term, the crime is known as "straafbaar feit" which consists of the words "strafbaar" and "feit." Strafbaar is interpreted as punished, and feit means reality. So strafbaar feit is part of the fact that crime can be punished. ${ }^{25}$ Furthermore, the classic function of punishment is to eradicate criminal behavior. While Parviz argues that crime in postmodernism is a function of social structure, dominant power, and mentality instead of the result of biological elements. ${ }^{26}$

In Indonesian law, complaint offense can only be processed if the victim complains on it. Therefore, the law enforcer cannot take the initiative to follow up on a case such as in normal crime, and in the complaint offense, the victim can revoke the report if the problem is resolved without taking legal action. There are two types of complaint offenses, namely absolute and relative. An absolute complaint offense is an offense that can only be processed if there is a complaint. The provisions listed in Articles 284, 287, 293, 310, 332, 322, and 369 of the Penal Code.

Meanwhile, the relative complaint is an offense that usually is a normal crime, but it can become a complaint once reported by relatives as stated in Article 367 of the Code. The Penal Code constitutes relative complaint offenses in several articles, namely Art. 367, Art. 370, Art. 376, Art. 394, Art. 404, and Art. 411. In this case, the perpetrators can be prosecuted selectively, and not all of them should be reported.

Complaints can only be submitted within six months after knowing that a crime has been occurred, or within nine months if the suspect lives outside Indonesia (as regulated by Article 74 Paragraph 1 of the Penal Code). Article 75 of the Penal Code also states that complaints can be revoked within three months after filing. Complaints that have been revoked generally cannot be filed anymore.

As an offense, the prosecution depends on the willingness of those affected by criminal acts or those who have an interest, in other words, those who have been charged with a crime have a role in determining whether the offender is prosecuted or not. Because prosecution is up to the will of victims, it opens the possibility of an alternative settlement between those affected by the crimes as a resolution outside the interference of law enforcement ${ }^{27}$.

In reality, the alternative settlement for certain crimes is often felt to be better and more beneficial than the judicial system. The loss of settlement through legal means, among others, is not familial in nature so it can break family relations, and from a legal standpoint the process of settlement is quite long, especially if it reaches the Supreme

24 Moeljatno. (2002). Asas-asas Hukum Pidana. Jakarta: Rineka Cipta, p. 54.

25 Hartanti, E. (2005). Tindak Pidana Korupsi. Jakarta: Sinar Grafika, p. 5.

26 Parviz \& Akbar. (2016). "Forming the Concept of Crime in Theoretical System of Postmodernism." Journal of Politics and Law, 9(9): 102.

27 Harahap, Y. (1986). Pembahasan Permasalahan dan Penerapan KUHAP. First Edition. Jakarta: Sarana Bakti Semesta, p. 20. 
Court level which takes years. The demands for justice from those affected by crime may no longer be fulfilled because the matter itself has been forgotten. ${ }^{28}$

Regarding complaints, the Penal Code also does not provide a limit of meaning because perhaps in the case, the drafting of the Penal Code considers more precisely if the purpose of complaint deemed necessary to be formulated explicitly in the Procedure of Penal Code. It is because the complaint is one of the legal efforts that required for certain offenses in the context of process of resolving a criminal case. P. A. F. Lamintang gave a limit regarding the complaints, as follows: "What is meant by klacht or complaint is a report with a request to be prosecuted against a certain person or persons." 29

\subsection{The Legal Reasoning behind Shifted Offense in the 2014 Copyrights Law}

There were three primary considerations in revising the 2002 Copyright Law which recognizes copyright infringement as a normal crime. In the Academic Draft of the 2014 Copyright's Bill, the legislators explained that the basis for changing the penal offense are as follows ${ }^{30}$ :

a. First, law enforcers cannot determine whether the violation has occurred only by comparing the goods resulting from copyright infringement with the original creation. Only the creator or copyright holder can be more sure to recognize which is the original creation and the imitation of the original creation so it can immediately report the occurrence of a violation of the exclusive rights of his creation.

b. Second, in carrying out legal proceedings, law enforcers may not immediately know whether a party has obtained permission to reproduce a work. Therefore, there must be a complaint in advance from the creator or the copyright holder.

c. Third, in practice, if copyright infringement occurs, the creators prefer compensation from the party who infringes the copyright rather than the imprisonment.

The legal binding between the creator and the suspect is mostly private to private (privaaatrechtelijk). So it is more appropriate to use passive systems, such as complaint offense. The normal crime for the 2002 Copyright Law means that law enforcement does not depend on an agreement or complaint from a party who has been harmed by a criminal act but rather is handed over by the officials to determine whether and where the criminal threat is against Copyright violations are conducted using public interests.

In practice, this is very detrimental to the creator. The copyright is an exclusive right, so ideally, the violation should be implementing a complaint offense because the person who knows the existence of the breach is the creator himself. This theory is further clarified by the burden of proof where investigators are perceived as having difficulties in proving the existence of criminal acts in the copyright field without reports from the owners. As already explained, the copyright law is declarative-based

28 Hamzah, A. (1987). Pengantar Hukum Acara Pidana. Jakarta: Ghalia Indonesia, p. 44.

29 Lamintang, P.A.F. (1984). Dasar-Dasar Hukum Pidana Indonesia. Bandung: Sinar Baru, p. 209.

30 Abdullah, A.G., dkk. (2008). “Naskah Akademik Rancangan Undang-Undang Tentang Hak Cipta (Perubahan UU No. 19 Tahun 2002)". Jakarta: Departemen Hukum dan HAM RI. 
protection. ${ }^{31}$ Even though the complaint submits to the Copyright Law, it must be understood that not all criminal rules in IP must be regulated by complaint offense. Separation is needed to understand the essential factors to determine an offense in IP. For example Copyrights, Patent, and Conventional Trademarks are fit for complaint offense because it requires expertise in determining the violation against the fair use. While on the other hand, the IP, such as protection of Well-Known Marks, the breach should be subject to normal crime considering the massiveness of crime and cultural violation concerning counterfeit products that need to be eradicated.

\section{Conclusion}

Based on the findings, the complaint offense of Copyright Law is more suitable when applied in the 4.0 Industrial Revolution. Considering the legal binding between the creator and the suspect is mostly private to private (privaaatrechtelijk), it is more appropriate to use passive systems, such as complaint offense. However, it is essential to note that separation of offense is needed to understand the essential factors to determine a penal offense in IP. Meanwhile, as a recommendation, the research suggests that the changes of offenses in the copyright law need to be integrated with law enforcement in Indonesia in terms of substantive regulation. It should consider the enforceability of the offense while law enforcement needs to understand the complexity of IP. Furthermore, it is necessary to make additional regulations on the reporting mechanism and the arrangement of complaints and reports through civil procedures.

\section{References}

\section{Books:}

Breakey, H. (2012). Intellectual Liberty: Natural Rights and Intellectual Property. New York: Routledge.

Fetterman, D.M. (1998). Ethnography Step by Step. London: Sage Publishing.

Hamzah, A. (1987). Pengantar Hukum Acara Pidana. Jakarta: Ghalia Indonesia.

Harahap, Y. (1986). Pembahasan Permasalahan dan Penerapan KUHAP. First Edition. Jakarta: PT. Sarana Bakti Semesta.

Hartanti, E. (2005). Tindak Pidana Korupsi. Jakarta: Sinar Grafika.

Kadir, A.M. (2001). Kajian Hukum Ekonomi Hak Kekayaan Intelektual. Bandung: Citra Aditya.

Lamintang, P. A. F. (1984). Dasar-Dasar Hukum Pidana Indonesia. Bandung: Sinar Baru.

Lindsey, Tim. dkk., (editor). (2002). Hak Kekayaan Intelektual, Suatu Pengantar. Bandung: Alumni.

Margono, S. (2003). Hukum dan Perlindungan Hak Cipta. Jakarta: Novindo Pustaka Mandiri.

31 Article 1 (1), Law Number 28 of 2014 
McCrudden, C. Legal Research and Social Sciences. on Mar, M.D \& Giudice, M (ed). (2017) Legal Theory and the Social Sciences. New York: Routledge, p. 19.

Moeljatno. (2002). Asas-Asas Hukum Pidana. Jakarta: Rineka Cipta.

Nurrachmad, M. (2012). Segala tentang HAKI Indonesia,. Yogyakarta: Buku Biru.

Rahardjo, S. (2000). Ilmu Hukum, Bandung; Citra Aditya Bakti.

Riswandi, B.A \& M. Syamsudin, M. (2004). Hak Kekayaan intelektual dan Budaya Hukum, Jakarta: RajaGrafindo Persada.

Saidin, O. (2010). Aspek Hukum Hak Atas Kekayaan Intelektual. Jakarta: RajaGrafindo Persada.

Salim \& Nurbani, E.S. (2013). Penerapan Teori Hukum pada Penelitian Tesis dan Disertasi. Jakarta: RajaGrafindo Persada.

Williams, B \& Smart, J.J.C. (1973), Utilitarianism: For and Against, Cambridge: Cambrige University Press.

\section{Journal Article:}

Barkan, S.M. (1982). “On Describing Legal Research”. Michigan Law Review, 80: 925-941.

Bloem, J. et. al, (2014), “The Fourth Industrial Revolution, Things to Tighten the Link between IT and OT". VINT Research 3: 11.

Moore, A.D. (2003). "Intellectual Property, Innovation, and Social Progress: The Case against Incentive based Arguments". Hamlin Law Review, 26(3): 602-630.

Moore,A.D. (2018). “Intellectual Property and the Prisoner's Dilemma: A Game Theory Justification of Copyrights, Patents, and Trade Secrets". Fordham Intellectual Property, Media, \& Entertainment Law Journal, 28(4): 833-862. Available at: https://ir.lawnet.fordham.edu/iplj/vol28/iss4/3

Parviz, P \& Akbar, V. (2016). "Forming the Concept of Crime in Theoretical System of Postmodernism". Journal of Politics and Law, 9(9): 102-109.

Paserangi, H. (2011). “Perlindungan Hukum Hak Cipta Software Program Komputer di Indonesia". Jurnal Hukum Ius Quia Iustum, 18 (Edisi Khusus): 20-35.

Presecaru, P. (2016). "Challenges of the Fourth Industrial Revolution". Journal of Knowledge Horizons-Economics, 8(1): 57-62.

Suwarni, W. (2019). “Obstacles to Enforcement of Book Copyright Law in Indonesia based on the Legal Structure, Legal Substance, and Legal Culture". International Journal of Advanced Research and Publications, 3(3): 153-157.

Teresia, R. (2015). “Perlindungan Hukum Hak Cipta terhadap Pemilik Lagu atas Perbuatan Pengunduhan Lagu Melalui Situs Tanpa Bayar di Internet." JOM Fakultas Hukum, 2(2): 1-15. 


\section{Research Report, Thesis, Dissertation:}

Abdullah, A. G., dkk. (2008). “Naskah Akademik Rancangan Undang-Undang tentang Hak Cipta (Perubahan UU Nomor 19 Tahun 2002)", Jakarta, Departemen Hukum dan HAM RI.

Priyatna, A (2016). "Penegakan Hukum terhadap Pelanggaran Hak Cipta dalam Pembuatan E-Book". (Tesis). Indonesia, Semarang: Magister Kenotariatan Fakultas Hukum Universitas Diponegoro.

\section{Internet:}

Scwhab, K. (2016). “The Fourth Industrial Revolution: What It Means, How to Respond", World Economic Forum, 14 January 2016. Available at https:/ / www.weforum.org/agenda/2016/01/the-fourth-industrialrevolution-what-it-means-and-how-to-respond/ 